\title{
THE IMPACT OF HISTORY LEARNING TO NATIONALISM AND PATRIOTISM ATTITUDES IN THE GLOBALISATION ERA
}

\author{
Subaryana $^{1}$
}

\begin{abstract}
Globalization is a process of interdependence almost in all life dimension of nations-state relationship and trans-national relations. In this case, it is not only capital, knowledge and technology but also social, political and cultural values of another country such as materialism, hedonism, individualism and pragmatism, have come to Indonesia, and influenced Indonesian people expecially teenagers. Recently, we can feel the national degradation that can be seen from the fading away the senses of nationalism and patriotism. Therefore, its efforts are needed to encourage the nationalism and patriotism character built up among the youth. One of the encouragement can be done through an effective history lesson. It isn't intended to the understanding of history lesson as a process of entrophy but in this case the history lesson must be viewed as a progresive lesson and has a future view. So nationalism hoped here is not jenggoism or chauvinism but it is humanist nationalism, and not blind patriotism but it is constructive patriotism.
\end{abstract}

Key words: Learning History, Nationalism Attitude, Patriotism Attitude, and Globalization.

${ }^{1}$ Subaryana, lecturer of History Education, IKIP PGRI Wates. For academic interest, the author can be contacted at office address: Jl. KRT Kertodiningrat No.5 Margosari. Pengasih, Kulon Progo, Yogyakarta. 


\section{Introduction}

Entering the third millennium, the world has been changing so fast and has very complex implications, one among others is the emergence of mutual dependence almost in all dimensions of life among nationstates and trans-national relations. The rapid changes are then called globalization. Globalization involves various aspects of life: political, economic, social, cultural, and science and technology. It is in line with what has been revealed by Naisbitt (1999) that there have been major changes in the lives of today as the impact of technological developments and have created 'new man'. Globalization is closely associated with modernity, according to Giddens (2001: 257) modernity is globalization inherent with the phenomenon consequences then combined with the circulation of reflection of character in shaping the risks and dangers events that support the life-affirming character. Further, Giddens (Ritzer, 2010: 240) states that modernity as a locomotive is very dynamic, it is a run fast world with a large increase in the rate, range and change of the prevailing system.

In this regard, the Indonesian people today are faced with many challenges: the existence of different value systems as well as technologies being tempted. All nations and all people are challenged to select carefully, which one that will be chosen for his own life as well as for the nation (Mardiatmadja, 1990: 226). In addition, not only capital knowledge and technology which have entered to Indonesia, but along with these entrance also social values, politics, and culture of other nations. In that regard, one crisis faced by Indonesia today is the values dilemma that arouse the identity crisis in every layers of society (Kartodirdjo, 1990: 15).
The above fact can be seen in the attitude of our young people who are actually glorifying foreign culture and values, such as liberalism, hedonism, pragmatism and materialism. This is in line with what has been said by Ali (1998: 246) that globalization and internationalization have spurred threats to the nationalism attitude, and driven to the identity crisis and the collapse of the local culture where national culture should be footholded. Identity crisis of youth can be traced from their behavior in daily life, shown by the behavior of the less loved to the culture of the nation and more loving foreign cultures: partying, dressing, and behaving like Westerns, even worse, they think that their culture is lower than Western cultures that they appreciate as modern culture. In accordance to that, Rais (2008: 52-53) states that our nation is still much mentally influenced by Inlanders, they mostly admire the thinking and culture of foreign nations, especially Western culture than their own nation. They are more trusting of strangers than Indonesian native. Likewise with mental officials and selfinterest group, they also tend to be more loving product or goods from abroad than the stuff of domestic products. Our young generation more familiar characters like Zoro, Avatar, and Rambo than our genuine heroes, like Diponegoro, Tuanku Imam Bonjol, Patimura and others. This is all an indicator of the erosion of the attitude or spirit of nationalism and patriotism among the young generation in Indonesia.

Seeing this fact above then it is time now to stir up the spirit of nationalism and patriotism, especially among the younger generation as generation of successors to continue the struggles of the nation. Therefore, it is very interesting to discuss 
further the effect of globalization to the declining of nationalism and patriotism attitudes, as well as, how the learning of history play an important role in preventing the declining attitude of nationalism and patriotism.

\section{Nationalism and Patriotism Decreased Due to Globalization}

Nationalism is a notion which states that individuals should be given the highest loyalty to the nation and the state (Kohn, 1965: 9), in other words, it puts the interests of the nation higher above personal interests and groups. Because of that nationalism is a fusion between a sense of loving the nation or nasionalitet and the spirit of patriotism (Nuseibeh, 1969).

Nationalism is a fundamental issue for a country, especially if the country has a very pluralistic primordial character. The claim of bhinneka tunggal ika (unity in diversity) that has been achieved, especially through political homogenization, has actually never been a reality historically, but rather a nation-building laden expectation agenda. Therefore, this is often felt flat. With its own interpretation, it is an imagined comunity as in Benedict Anderson's term. Anderson (1999) has used this term to describe similar meanings of imagination or fantasy. The discussion is more suitable to use the analysis of political history to explain the link between collective imagination that bind a community. People are united as a country because of the equality of blood identity, ideology, and interests. Meanwhile, according to Kahin (1995), Indonesian nationalism is bound in the form of unity of Indonesia, that has actually been interwoven for centuries through the long political, social and economic processes. The form of nationalism should still be adapted to the time circumstances.

Meanwhile, Muhammad Ali Embi in Hanim and Ahmad (2011: 103) states that the word patriotism comes from two Greek syllables, the Pater, means father and patris means land. The combined of two-syllable word in English language means the love of a fatherland that in Indonesian language means love for the motherland. Thus patriotism as a love to a country where we belong.

According to Sargent (1986: 28) there is actually no different in meaning between patriotism and nationalism. Nationalism includes patriotism, and the demands for action with the aim of strengthening the state or in other words the feeling of patriotism is love of country. Therefore, the soul or spirit of patriotism is to realize nationalism.

Patriotism is an allegiance to certain group, such as ethnicity, race, political party, etc. (Staub \& Schatz (1997). He further divides patriotism into two parts: (1) Blind Patriotism, and (2) constructive patriotism. This constructive patriotism in Hubermas terms (Latcheva, 2010) is a constitutional patriotism, that is patriotism which is based on the constitutional principles and human values that are universal rather than emphasizing the historical and cultural identity. From the concept of constructive or constitutional patriotism mentioned above, it is worth mentioning that a patriot is the one who respects and loves both the groups (parties, tribes, nations or states), but more than that he must endorse human values and the Constitution and willing to accept constructive criticism. 
Nationalism and patriotism has inspired our leaders to fight for freedom from the ruled of the invaders. They realized that the weakness of the country is the pride of each local areas or tribes, so that the invaders felt easier to confront our heroes struggle. Through the divide at impera tactics, the Dutch have proved the effectiveness of this tactics in front of our fighters or heroes at that time. It's all an attitude indicator that Indonesian nationalism has not yet built and cristalised among the people of Indonesia. The attitude of nationalism and patriotism of Indonesia began visible and grew especially at the beginning of the twentieth century, marked by a national movement. National movement spearheaded by the students has become a new stage in the development of Indonesia's history. The students scholars have opened their minds after they saw the struggle pioneered by other nations to pursue their nation independence from the shackles of colonialism. (Subaryana, 2010).

Indonesian national movement has actually shown the spirit of nationalism and patriotism, especially when Youth Congress II in Jakarta, that has generated Youth Oath Sumpah Pemuda. Through this oath, the youths promise to have the same feeling as having one nation, one country and one language that is Indonesia.

These all have enforced the spirit of togetherness in facing the struggle against the invaders through uniting the same steps and direction. Along with the development of nationalism and patriotism, the growth of the spirit of national struggle has reached its culmination when the declaration of independence of the Republic of Indonesia on August 17, 1945.
In the early days of independence, nationalism was the main inspiration within the hearts of the fighters in maintaining the sustainability of the independence that has already been embraced. Although it is also undeniable that some are still growing their local spirit and narrow patriotism. These negative characters had consciously been used by the Dutch as their political strategy to return to rule Indonesia, through setting up puppet states, such as: Pasundan state, Sumatra countries, countries of Eastern Indonesia and several uprisings of specific groups, such as Andi Aziz in Sulawesi, PRRI / Permesta, IN / TII, RMS and others. But it did not last long and eventually returned to the Unitary State of the Republic Indonesia. The attitude of nationalism and patriotism of the 45 generation cannot be denied and doubt, but, how about the development of the attitude of nationalism and patriotism especially in this era of globalization.

According to Lodge (in Winarno, 2004: 39) globalization is a process that puts the world community to be able to reach out to each other or touch each other in all aspects of life: social, political, cultural, economic, technologicalandenvironmental.Indonesia nation as part of the nations of the world can not circumvent this globalization. Meanwhile, Giddens (2005: 95-96) states that one aspect of the dialectical nature of globalization is the push and pull between a tendency toward centralization inherent in the reflectivity of the system in one side and state sovereignty in the other. Now, how this nation then has to conform to it.

In this borderless world era, a world without borders, and the influence of globalization is so intense and aggressive, nationalism and patriotism are two things that the nation desperately need. 
Globalization triggers the rise of a cosmopolitan global culture that will increasingly swallow up and erode a culture and national identity. Foreign cultural imperialism has attacked indigenous Indonesian culture. Foreign culture began to permeate the soul of the people of Indonesia and can weaken the identity and national consciousness. They are adrift in the currents that are always moving fast. Therefore, globalization can lead to the decline of the attitude of nationalism and patriotism.

The current climate of pragmatism has very massively developed, but nationalism as an idea, passion and idealism would not give room for pragmatism. But the objective reality of nationalism has intrepretedly forced into contact with the values of pragmatism. But if pragmatism that has been put forward, it will clearly endanger and distort nationalism. The effect can be temporary, or permanent, depending on how the nation's strategy reacts to this. According Urbaningrum (1998: 394) nationalism and globalization can be contrasted or assimilated; it all depends on the intelligence to read the direction and substance of globalization, therefore, the alertness in confronting this effect and not to unwisely accept all the manifestation of globalization.

Globalization has led to the rise of mass consumerism, in which the material benefits are needed by people all over the world, and technology products, as well as seeking new markets in Western capitals. Commodityflowandappealofconsumerism makes national boundaries and rules of the government became increasingly powerless and irrelevant (Qomariah, 2010). In line with the above, the idea of
Michel Foucault in his famous manuscript of The Archaeology of Knowledge (1972), in which Foucault has unmasked the superstructure system dominance over the discourse, with the knowledge and power relations. In Foucault's view of postcolonial theory will demonstrate knowledge of how the West has dominated Eastern people in various ways, such as mass media, both print and electronic. Through this time the western media has influenced the younger generation. Pop culture has been pervasive in the hearts of many young people in the Eastern world, including Indonesia.

Globalization has both positive and negative effects for Indonesia, among the positive effects are the growing of democratization in Indonesia, therefore, the principles of openness are in the forefront of our government; the opening of international markets, if we are able to positively respond to this, will undoubtedly be able to increase employment and generate a lot of foreign exchanges, so it will improve the well-being of the nation; through globalization, we will also be able to imitate a high work ethic and discipline as well as the progress of science and technology of other nations that have already been developed, so it will be able to advance and prosper our nation and can successfully align with other developed nations.

While the negative impacts include: the excessive liberalism that will make people get out of control and lack of respect for the norms of decency, courtesy and friendliness that characterizes the people of Indonesia, even ideological liberalism may threaten the ideology of Pancasila which in turn will obviously eliminate the sense of nationalism and patriotism; 
globalization in the economy would also threaten Indonesia's economy if we are not ready to challenge this, even now, it has already seen that the love for the love of foreign products are higher than the love of domestic products, the inclusion of modern Western values has also been evicted values and culture of Indonesia and as its consequence, the young nation generation would also loose their identity; capitalist and neo-liberal economic development will give impact on the widening economic gap between the rich and the poor. Lack of concern and indifferent attitude would threaten togetherness and mutual support which in turn will cause the decline of a sense of concern for the nation and the state.

The fact mentioned above will clearly have an impact which is quite unusual for Indonesian nationalism and patriotism of the nation, especially among the younger generation. Although the impact is not direct, but as a whole will be able to cause a sense of nationalism and patriotism in the nation and the state becomes less and less (Darmiyati, 2010). This is in line with what was said by Azra (2002) that the basic unity that has been built by the founders of the nation is now faced with the challenge of declining public morality, the waning of the values of nationalism, national identity negligance, increasing conflicts between tribes, races and religions, and to the more strong issue of national disintegration.

The flow of information is so fast and easy to $\log$ in to our country, if we do not deal wisely and intelligently, it obviously will giveimpact to the decline of nationalism and patriotism attitude of the Indonesian nation. This can be seen in everyday life displayed by our young people, such as for the sake of freedom and openness, they become anarchic in their demonstrations and trample the norms of decency and civility. They no longer respect the leaders of this nation even with their casually threw obscenities and trampling photo or image of the president. They also do not realize that what they do has been disturbing the peace and comfort of the community and hurts the feelings of others.

Today in Indonesia, many people are unaware to adore foreign world, almost in all fields: social, cultural, economic, political, science and technology, even worse they irrespect their own nation. They also begin to lose the pride of the struggle pioneered by the heroes in establishing the republic, they even question the credibility of the struggles of the heroes that we respect, maybe this is the curse of the ancestors. For example, Compass Research Team presents the results of questionnaires of Indonesia in the national crisis, on August 6 to 8, the results obtained that $60 \%$ of respondents do not feel proud as people of Indonesia, $24.3 \%$ feel proud, $3.1 \%$ do not know and $12,6 \%$ feel ordinary (Supardan, 2004: 27). Another example, some paid supporters on the 26th Sea Games in Palembang who consist of junior school, high school, vocational and MA students, and coordinated by the guidance counselor, and deployed by the Department of Education and Sports (Wartakota, 20 November 2011). They are teenagers who are looking for self-identity, but instead, taught to have pride of the attributes other countries, even when the game was held against their own country league. It is not surprising if they also will surrender and leave the country for the sake of their self and other certain group interests. 
Theideology of materialism and hedonism has been pervasive in the hearts of some of the leadership of this country. They are much preoccupied with addressing their needs and satisfaction in life, despite the indulgence in lust and greed, such as collusion, corruption and nepotism become common in our beloved country. In fact they are proud of what they earn by greed despite hurt other people. Nationalism and patriotism exist only in the political jargon when they will compete for the leadership of this country positions. However, after they manage to achieve what they want, their people or constituents will leave and not enjoy it, even without realizing, the people have become Victims for realizing their ambition. As a concrete example, lately almost every day we hear news about the actions of the legal, tax and political mafia, all they did was for the sake of satisfying their lust, the materialistic and hedonistic lifestyle that is rarely encountered in the age of nation struggle. This fact has clearly become indicators of the declining of nationalism and patriotism attitudes of Indonesian nation today.

Today, many national observers and experts complain to the declining of the spirit of nationalism and patriotism in the community. Some students and young people do not know the national anthem song of Indonesia Raya and the names of national heroes, even they like to ask for assistance to foreign nations, and ask for greater autonomy of authority, and so on. Even today, the spirit of nationalism has become tribalism nativistic. Unity that had been imprinted are already cracks even tend successively toward disintegration, the increasing number of horizontal conflicts are increasingly worrying and led to the balkanization of the national life. The friendly and personable nation as well as the strong spirit of mutual cooperation has now turned into fury and individualistic nature. This is due to the shallowing of the values championed by the founders of this country for many years. Our younger generation as if they are experiencing alienation from their heritage. According Widja (2002: 7) who has argued that generation gap has now happened especially in comprehending the values of nation history and meaning and has suggestively uprooted the generation from the historical values of the nation.

Seeing the reality mentioned above, it becomes our duties to imprint the values of nation history especially the spirit of nationalism and patriotism. It is given that nationalism and patriotism were not only required when the Indonesian people fighting to win and retain their independence, but it is still needed to be maintained and cultivated along with the spirit of the time.

\section{The Nature and Purpose of History Education}

Etymologically the word "history" comes from the Arabic word syajaratun which means tree and is similar to genealogy or family tree. In other languages the term history is equivalent with the word history (English), histoire (French), geschicte (Germany) or geschiedenis (Netherlands). Until now there is no definition of history that can be universally accepted. There are several definitions of history suggested by some experts: March Bloch considers that history is a study of man in the context of the time; E. Berheim regards history as a science of human development; EH Caar has revealed that a history of interaction between the historian to the facts of history and unending dialogue between the present 
with the past; Burckhardt has seen history as a record of a time that found and seen for generations in the time of others. (Carr, 1965; Kochar, 2008 and Sjamsuddin, 2007). From the definitions of thehistorians mentioned above it can be concluded that history is related to the human sciences in the past, which is based on historical facts and are beneficial to humans in the future. Therefore, by examining the opinions of the historians mentioned above, it may help to understand the historical ontology.

In more detailed, the nature of history according to Kochhar (2008: 3-6) is the science of human, the history of the human study within the time of human history also examines the scope of the space, explaining the history of the present, history is a dialogue between past events and developments to the future, history is the story of the development of human consciousness in both individual and collective aspects, and continuity and relevance are both very important in history.

The history of education is a very important educational material to achieve the four objectives. The first goal of history education is providing basic and in-depth educational materials, and based on the real experiences of the nation in the past to build awareness and understanding of self and his nation. Second, the history of the educational material is specific educational materials in developing the ability to think logically, critically, analytically, and creatively, because it is related to something that is fixed in the life of the nation in the past and always with respect to human behavior that is controlled by logical, critical analytical and creative thinking, in harmony with the challenges faced at certain related time. Third, the history education presents materials and examples of ideal leadership, pioneering, attitudes and actions of people in their group that lead to changes in the human life. Fourth, human life is always associated with the past because even if the action results in a final challenge but the results of such action always has an effect that is not only for his time but also the effect on the community when they run his new life, and therefore, historical events become the source as bank of examples to be used and adapted as an action in facing the challenges of life today (Hasan, 2011).

The four meanings have given "knowledge of the past that contains the values of wisdom to be used to train intelligence in shaping attitudes, character and personality of the students."

The common goal of teaching history introduced by Kochhar (2008: 27-37), are as follows:

1. Developing an understanding of self.

2. Providing an accurate description of the concept of time, space, and society.

3. Creating communities who are able to evaluate the values and achievements accomplished by their young generation.

4. Instilling intellectual skills (critical thinking) and teaching tolerance.

5. Expanding the horizons of intellectuality.

6. Teaching moral principles.

7. Embedding the principle of orientation to the future.

8. Trainingstudentstorecognizecontroversial issues. 
9. Helping to solve social and individual problems

10. Strengthening the sense of nationalism.

11. Developing international understanding. Meanwhile, according to Wineburg (2001) history should be taught in schools as history has the potentials - which are only partially accomplished - to make us human are humane. The past becomes a very useful source for our daily life. The past which is not suitable to the needs of our present or not in tune with our needs today can be got rid of or ignored. In addition to learning history, it is expected for us to think historically.

Thus, the study of history as a human life in the past is very important to be learnt by the next generation, because the values of the past are necessary to face future challenges. However, we need not have to create an entropic generation, because idealism of the past is not necessarily in accordance with the present.

\section{Building up the Nationalism and Patriotism Attitudes through History Learning}

Learning has existed since the history of mankind is existed in this earth, but always progressing with the development of human creativity. Learning is experienced by humans throughout life and is applicable wherever and whenever. They need in thenarrowsense, learning is a process or method performed so that learners can perform learning activities. Meanwhile, in the broad sense, it is a process or activity that is systematic, systemic, interactive, and communicative among educators with learners, learning resources and environment to createconducivelearning conditions for students, both in and outside classes and whether it is physically attended by educators or not, the aim of learning is mastering the defined competencies (Arifin, 2009: 10).

According to Law no. 20 of 2003, Chapter I, Article 1 Section 20, states that learning is a process of interaction of educators with learners and learning resources in a learning environment. It is concluded that learning is an activity where there is a process of interaction between teachers and students and learning resources in conditions conducive to achieving the set of learning objectives or competencies to master.

Thus, the learning activity is an activity that involves several components, including: 1) purpose, ie statements about changes in behavior (cognitive, psychomotor, affective) that are desirely happened after the students participating in learning activities, 2) teacher, is someone who acts as manager, catalyst, and other roles that allows the effective teaching and learning activities or Courses, 3) learner is a person who acts as a seeker, receiving, and storing the content needed to reach the goal; 4) subject matter, that all information in the form of facts, principles , and concepts needed to achieve the objectives, 5) method, an orderly manner to provide the opportunity for students to get the information needed to achieve this goal 6) media, the teaching materials with or without equipment that is used to present information to students; and 7) evaluation, the specific way that is used to assess the process and its outcome.

Learning history has an important role in the development of young people, such as those expressed by Daniel (1972) and Soedjatmoko (1990) that the teaching of history is an effective means to inculcate 
an attitude of loyalty and responsibility to the citizens of the state and nation in other words, it is capable of forming nation's personality. With the deepening the understanding of the history of his nation, people will be able to shine and internalize the personality his nation (Soedjatmoko, 1980).

History is also described as a torch that can light up the future that is still dim (Haikal, 1989). It is likely expressed by Gordon in Widja (1988) who states that history as a collective memory that serve as the foundation for self identity and pass on to the younger generation who become collective pride and dedication for the nation and country. Sartono Kartodirdjo (in Poesponegoro and Notosusanto, 1984) states that the history of Indonesia, which describes the condition of Indonesia both in joy and sorrow periods, and the role of some historical figures to evoke a sense of pride of the young generation so as to be able to strengthen their personality and identity.

Meanwhile, Ali (1963: 291) mentions the learning objectives of national history are: generating and developing national spirit; arising passion in realizing the ideals of nationhood; sensitizing students on national ideals and the struggle to realize the ideals of the national all-time. Correspondingly, Hill (1956: 10) states that the function of teaching history in schools is to help students develop a sense of patriotism, and understand customs or ways of life. More explicitly Suparno (1995) argues that the teaching of history as a means of strengthening national identity and integration.

In viewing the opinion of some experts above, it can be concluded that the teaching of history will be able to evoke the spirit of nationalism and patriotism for young people in Indonesia. The importance of teaching history can be seen from the result of Kompas poll on July 9, 2010, that found that $90 \%$ of respondents agreed that the teaching of history in schools played an important role to shape the character or the character of the nation.

The foregoing seems to have inspired the drafters of the curriculum now, because it's in KTSP (Education Unit Curriculum) on the basis that the purpose of learning in school is for students to acquire the skills of historical thinking and historical understanding. Through teaching history students are able to develop competence to think in chronological order and have knowledge of the past that can be used to understand and explain the process of development and change in society as well as social and cultural diversity in order to find and foster national identity in the midst of the world community. Learning history is also intended to make students aware of the diversity of life experience in their respective communities and their different perspectives on the past to understand the present and build the knowledge and understanding to face the future (Curriculum Center, 2006).

As explained in the previous section that in order to understand history as a whole, the learners must be able to comprehend the values embeded in the historical events they are studying. The noble values inherited by the former Indonesian, according Sutrisno Kutoyo (1983), include: the devotion to The Almighty God, mutual support, respect for parents, love for the nation and the state, unity, patriotism, humanity, democracy, solidarity, 
agreement findings musayawarah, and so on. The foregoing appears to have inspired the authors of the curriculum now, because it's in SBC (School Based Curriculum) on the basis that the purpose of teaching in the school is to enable students to acquire the ability to think historically and understand history. Through teaching history students are able to develop the competence to think in chronological order and have knowledge of the past that can be used to understand and explain the process of development and change in society and the social and cultural diversity in order to find and foster national identity in the midst of the world community. Learning history is also intended to make students aware of the diversityoflifeexperienceintheir respective communities and the different perspectives of the past to understand the present and to build knowledge and understanding to face the future (Curriculum Centre, 2006).

Meanwhile, the teaching of history in schools has not optimally been implemented, this is due to the persistence of the teachers who do not even have a professional background graduated from history education department that have to teach history at the school. Besides, the absence of teaching history learning facilities, and students' perception whoview history lessons as boring and uninteresting subject. Therefore, it is necessary to optimize the efforts in the implementation of the teaching of history.

In an effort to train students to be able to think of history as well as understand and actualize the historical values, then constructivist approach seems to be appropriate. Constructivism is a learning process that explains how knowledge is developed in human beings. The elements of constructivism have long been practiced in the learning and its processes since the primary, secondary, or university levels of education, although still not clearly visible. Based on the ideology of constructivism, in the learning process, the teacher does not necessarily transfer knowledge to students in the form of an all-perfect. In other words, students must build a knowledge based on their experiences.

Learning is the result of the efforts of students themselves. The pattern of development of science in schools is in a form of a scheme, a mental activity that is used by learners as a raw material for the process of reflection and abstraction. Students' mind will not face reality in the form of the alienated in the neighborhood.

Reality known by the students is a reality that they coach for themselves. Students actually have to have a set of ideas and experiences that will form the cognitive structure of their environment. For assisting learners in developing concepts or new knowledge, teachers should predict cognitive structures that exist on them. If new knowledge has been adapted and absorbed to be a part of the strong grip of them, then the new framework of some form of knowledge can be fostered.

John Dewey has reinforced the constructivist theory by saying that competent educators should implement teaching and learning as the process of preparing or fostering a sustainable experience. He has also emphasized the importance of collaboration or involvement of learners in every teaching and learning activity.

Characteristicsofaconstructivistteaching history are: students are actively involved in learning; students learn significant historical 
materials in working and thinking; students learn how to learn them; new information must be linked to other information that should be integrated with the scheme so that students have an understanding of information (material) complex; learning orientation is an investigation and discovery (inquiry) and oriented towards problem solving (Subakti, 2010).

Constructivist approach help students acquire knowledge and are able to apply the knowledge in new situations. This is due to the impression of constructivist approach to teaching and learning of history and its ability in helping students understand the concepts and mastering better the content embeded in the history lesson.

In the study of history, Postcolonial view- raising contemporaryissuesin history - including the impact of globalization in various student social life should also be used. This is because until now continuity still happens in colonial practices and appears in the presence of multinational companies characterized by the strong flow of capital, goods and services, weapons and media information that has power relations that are almost as large as the colonial era (Supriyatna, 2007).

In the history learning then the teacher factor is also very important, according to Kochar (2008) qualities that should be owned by history teacher are both including the material and technical masteries. In the material mastery quality, the history teacher must complete his academic degrees in history and master the related sciences such as modern languages, history of philosophy, literary history, and geography. In the technique mastery quality, history teacher should comprehed various methods and techniques of teaching history, the history teacher must create a conducive learning environment, so that students feel comfortable and enthusiastic in learning the history lessons. Because of the importance factor of teacher in history, the historical values inherent in various history events, including the value of nationalism becomes the duty and obligation of teachers to impart to their students.

According to Winarno Surakhmad (1980) coaching attitudes and values is more appropriate to use values clarification method, that is through explaining, uncovering and detailing the values. This coaching can also use the TELSTAR Model (Tune in, Explore, Look, Sort, Test, Act, and Reflect), especially in explaining the values of social justice with the students through finding themselves under the guidance of a teacher or inquiry (Marsh, 2008: 157).

Learning history as a means to present the factual knowledge of the events that happened in the past, so the students are expected to understand, appreciate and actualize the knowledge in their everyday life. Therefore, the teaching of history should be able to cultivate an attitude of nationalism and patriotism. But nationalism needs to be revitalized in accordance with the reform spirit that the point is the development of civil society and the democratic rule of law. So patriotism is directed to the constructive patriotism or constitutional patriotism and not to narrow patriotism or regionalism.

Bylearninghistory and othercharacters education, the younger generation are expected to understand the cultural values and the struggle of their people, which in turn they will be able to understand and actualize these values in their daily lives. This course will be used as a filter against the 
foreign culture values swift current flowing into Indonesia in this era of globalization in order to create interesting and effective learning of history. According to Supardan (in Tribun Jabar, July 17, 2012, p. 10) a change in the paradigm of teaching history is required and this change has actually been pioneered by Robinson through changing from a long history that is too rigid and limiting the political history toward new history that includes multi-disciplinary of socio-economics, culture, education. Even its visible change is so intense that includes the educational philosophy of history, ie from Perenialism towards essentialism, even social reconstructionism and melt into an eclectic history.

Unfortunately, our perception to the past history is still too narrow, even our young generation are still undervaluation to the history. They forget that in order to face the challenges of our times and the future they need to learn from what has happened in the past. Weaknesses that existed in the past and we have to fix and also the strengths of the past should be improved. This is the key steps to our success in life at present and in the future.

\section{Conclusion}

From the above discussion, it is obvious that globalization is a situation that can not be avoided and must be dealt with, because it is the demands of the times. In the era of globalization certainly universal values will go easily into Indonesia. Unfortunately, we still often swallow these values are raw, as a result, many of us are even more glorifying foreign nations and their cultural values rather than our nation values and culture. This is even reflected in the behavior of their lives, such as idolizing foreign products and the loss of a love for domestic products. The emergence of individualist attitudes and reduced social care for others has become an indicator of the erosion of the attitude of nationalism, especially among the younger generation to relay the struggle of our national successor.

Through history teaching students are now able to develop competencies for critical and chronological thinking and have knowledge of the past that can be used to understand and explain the process of development and change in society as well as social and cultural diversity in order to find and foster national identity in the midst of the global community.

Somehow, wehave to faceglobalization, because it requires an intelligent and prudent attitude in facing the global change. In addition, it is necessary to have an effective teaching of history that is not just as a process of entrophy learning but a progressive and visionary learning for future. Through teaching history students are able to develop competencies to think critically and chronological as well as having knowledge of the past that can be used to understand and explain the process of development and change in society and the social and cultural diversity in order to discover and develop the national identity in the midst of the world.

Through the study of history, it is expected to foster the spirit of nationalism and patriotism. The spirit of nationalism fostered not narrow nationalism, such jenggoisme or chauvinism, but a humanist nationalism. So is patriotism grown not blind patriotism, but constructive or constitutional patriotism. Thus will Bung Karno "Red Coat" remain our resume to be practiced. So does the philosopher of 
Mulan Kundera phrase who states that "if it will destroy a nation, destroy the first history" seem to be contemplated!

\section{REFERENCES}

Abdulah, T. (1985). Ilmu Sejarah dan Historiografi (Arah dan Perspektif). Jakarta: Gramedia.

Abdullah,T.(1999).NasionalismeIndonesia:

Dari asal-usul ke prospek masa depan. Jakarta: MSI dan Arsip Nasional RI.

Abdullah, T. (2001). Nasionalisme \&

Sejarah. Bandung: Satya Historika.

Aldrige, Jerry and Goldman, Renitta. (2002).

Current Issues and Trends in Education.

Boston:Allyn and Bacon

Ali, F. (1998). "Refleksi Tentang Semangat

Kebangsaan dan Kesatuan Nasional",

Dalam Ismed Hasan Putro (ed). Indonesia Memasuki Milenium III Gagasan dan Pemikiran Edi Sudrajat. Surabaya : Pusat Studi Indonesia.

Ali, Moh. R. (1963). Pengantar Ilmu Sejarah Indonesia. Djakarta : Bhratara.

Anderson,B.(1983).ImaginedCommunities:

Reflections on The Origins and spread of

Nationalism. London : Verso Press.

Arifin, Z. (2009). Evaluasi Pembelajaran,

Prinsip, Teknik, Prosedur. Bandung:

Remaja Rosdakarya.

Azra, A. (2002). Paradigma Baru Pendidikan Nasional. Jakarta : Penerbit Buku Kompas.

Banks, James A. (1990). Teaching Strategies for The Social Studies: Inquiry, Valuing and Decision-Making. New York: Longman

Bartal. (1976). Prososial Behavior. New York: Jhon Wiley and Sons

Benjamin. (1991).AStudent Guideto History. New York (USA): St. Martin Press

Carr, E.H. (1965). What Is History?. New York: Macmillagn.
Foucault, M. (1972). The Archeology of Knowledge. New York : Pantheon.

Giddens, A. (2001). Tumbal Modernitas. Terjemahan. Yogyakarta : IRCiSoD.

Giddens,A.(2005).Konsekuensi-Konskuensi Modernitas. Terjemahan. Yogya- karta : Kreasi Wacana.

Gottschalk, L. (1985). Mengerti Sejarah. Jakarta. UI Press

Haikal, H. (1989). Tutwuri Handayani Dalam Pendidikan Sejarah, Suatu Penelitian Kepustakaan. Jakarta : Depdikbud.

Hasan, S. H. (2011). Pendidikan Sejarah: Orientasi dan Strategi Pedagogis. Makalah disampaikan pada Konferensi Nasional Sejarah Ke IX, Jakarta 5-7 Juli 2011.

Hill, C.P. (1956). Saran-Saran Tentang Mengajarkan Sejarah. Jakarta: Perpustakaan Perguruan Kementrian P.P \& K.

Kahin, G. Mc. T. (1995). Nasionalisme dan Revolusi di Indonesia. (terj. Nin Bakti Sumanto ), Surakarta : UNS Press.

Kartodirdjo, S. (1990). Kebudayaan Pembangunan dalam Perspektif Sejarah. Yogyakarta: Gadjah Mada University Press.

Kartodirdjo, S. (1999). Multidimensi Pembangunan Bangsa; Etos Nasionalisme dan Negara Kesatuan. Yogyakarta : Kanisius.

Khon, H. (1965). Nationalism : Its Meaning and History. Malabar, Florida : Robert E. Krieger Publishing Company.

Kochhar, S.K. (2008). Teaching of History. Terj. Purwanta dan Hardiwati. Yogyakarta: Grasindo.

Kutoyo, S. (1983). Suatu Catatan Tentang Kesadaran Sejarah; Pemikiran Tentang Pembinaan Keadaran Sejarah. Jakarta : Depdikbud. 
Latcheva, Rossalina (2010). Nationalism versus Patriotism, or the Floating Border? National Identification and Ethnic Exclusion in Post-Communist Bulgaria. Jurnal of Comparative Research in Anthropology and Sociology. Vol.1 (2). P 187 - 216. ditelusuri di http://compaso.ro doctorat.sas.unibuc. ro/.../Issue2_RossalinaLatcheva_ Nationalism.pdf

Lee, P.J. (1984). Learning History. Liverpool (Britain): Heineman Educational Book

Mardiatmadja, B.S. (1990). "Pendidikan dan Pendidikan Nilai” dalam Dick Hartoko (ed.). Memanusiakan Manusia Muda. Yogyakarta : Kanisius.

Marsh, C.(2008). Studies of Society and Environment; Exploring the Teaching Possibilities. 5Th ed. Australia : Pearson Prentice Hall.

Naisbitt, J. (1999). High Tech-High Touch : Technology andOurSearchforMeaning. New York : Broadway Books.

Nuseibeh, Hazem Zaki. (1969). GagasanGagasan Nasionalisme Arab. Trj. Sumantri Mertodipuro. Jakarta : Bhratara.

Poesponegoro, Marwati Djoenoet and Nugroho Notosusanto, (1984). Sejarah Nasional Indonesia I. Jakarta: Balai Pustaka.

Rais, A. (2008). Agenda Mendesak Bangsa:

Selamatkan Indonesia. Yogyakarta: PPSK Press

Ritzer, G. (2010). Teori Sosial Postmodern. Terj. Muhamad Taufik. Yogyakarta: Kreasi Wacana.

Sharma, S.K. (2008). Teaching of History. New Delhi: Lotus Press

Sjamsuddin, H, (2007). Metodologi Sejarah. Yogyakarta: Ombak.

Soedjatmoko. (1990). Dimensi Manusia Dalam Pembangunan. Jakarta : LP3ES
Subakti, Y.R. (2010). Paradigma Pembelajaran Sejarah Berbasis Konstruktivisme, Dalam. SPPS, Vol. 24 No. 1 April 2010).

Subaryana. (2010). Menurunnya Sikap Nasionalisme di Era Globalisasi dan Upaya Pencegahannya. In Jurnal Akademika. Vol. 9, No. 1, April 2010.

Supardan, D. (2004). Pembelajaran Sejarah Berbasis Pendekatan Multi Kultural dan Perspektif Sejarah lokal, Nasional, Global Untuk Integrasi Bangsa. Disertasi. Bandung : Universitas Pendidikan Indonesia (UPI).

Supardan, D. (2012). Membawa Siswa ke Situasi Riil Sejarah, Pembelajaran Sejarah Lokal, Nasional dan Global. Tribun Jabar (17 Juli 2012)

Suparno, S. (1995). "Pengajaran Sejarah SebagaiSaranaMemperkuatJatiDiriDan Integrasi Bangsa. Dalam. Depdikbud. PengajaranSejarah.Kumpulan Makalah Simposium. Jakarta : Depdikbud.

Staub, Ervin. \& Schatz, R.T. (1997). Manifestations of blind and constructive patriotism: personality correlates and individual-group relations. In Bar-Tal, Daniel \& Staub, Ervin (ed). Patriotismin the Lives of Individuals and Nations. Chicago: Nelson - Hall Publisher.

Supriatna, N. (2007). "Pembelajaran Dalam KTSP”. Paper in semiloka guru-guru Sejarah MGMP Sejarah, Bandung, 5 April 2007.

Surachmat, W. (1990). Mewujudkan NilaiNilai Hidup dalam tingkah laku: Sebuah ikhtisar Pedoman metodologik. Bandung : Tarsito.

Tasa, R.H.M. (2009). Pemuda dan Nasionalisme, Refleksi 101 Tahun Kebangkitan Nasional. Yogyakarta : Pustaka Timur 
Urbaningrum, A. (1998). "Pemuda, Winarno, B. (2004). Globalisasi Wujud Nasionalisme dan Perspektifnya bagi Imperialisme Baru, Peran Negara Kehidupan Bangsa”, dalam Ismed Dalam Pembangunan. Yogyakarta : Hasan Putro (ed). Indonesia Memasuki Milenium III Gagasan dan Pemikiran Edi Sudrajat. Surabaya: Pusat Studi Indonesia

Widja, I Gde. (1987). Pengantar Ilmu Sejarah. Singaraja : FKIP UNUD

Widja, I Gde. (2002). Menuju Wajah Baru Pendidikan Sejarah. Yogyakarta : Lapera Pustaka Utama. Tajidu Press.

Wineburg, S. (2001). Historical Thinking and Other Unnatural Acts Charting the Future of Teaching the Past. Philadelphia, PA: Temple University Press.

Wiriaatmadja, R. (2003). Pendidikan Sejarah di Indonesia Perspektif Lokal, Nasional, dan Global. Bandung: Historia Utama Press 